\title{
NO WAY OUT: HOW PRIME-AGE WORKERS GET TRAPPED IN MINIMUM-WAGE JOBS
}

\author{
Heather Boushey
}

\begin{abstract}
Most minimum-wage workers are adults making significant contributions to the total family income. In the early 2000s, less than one-in-five workers earning the minimum wage was under the age of 20 and balf were between the ages of 25 and 54. Using the Survey of Income and Program Participation, this article finds that prime-age workers in minimum-wage jobs are likely to "get stuck" at those jobs. Over a third of prime-age adults in minimum-wage jobs remain in minimum-wage jobs three years later. Not all adults in minimum-wage jobs have the same chance of moving into a job paying more than the minimum wage. The probability of moving out of a minimum-wage job is higher for men, native-born citizens, those with union jobs, and those that change industry and/or occupation. The probability of staying in a minimum-wage job was greater in the early and mid-1990s, as compared to the late 1990s and early 2000 s.
\end{abstract}

The minimum wage has not been increased since 1997. Since then, although the minimum wage has remained at $\$ 5.15$ in nominal terms, the value of the minimum wage has fallen by nearly a sixth in inflation-adjusted terms. Compared to a few years ago, fewer workers earn the minimum wage (after inflation adjustment) today because the inflation-adjusted value of the minimum wage has fallen so much. However, what has not changed is that it is relatively uncommon for prime-age workers to move out of minimum-wage jobs, once they have one.

Minimum-wage workers are not all teenagers looking for some fun money; a substantial share are adults making significant contributions to the total family income. In the early 2000s, less than one-in-five workers earning the minimum wage was under the age of 20 and half were between ages 25 and $54 .{ }^{1}$ In 2002, minimum-wage workers earned an average of 68.0 percent of their total family income (Chapman and Ettlinger, 2004). However, even if a worker is employed full-time, full-year at the minimum wage, he or she earns just $\$ 10,300$, putting him or her below the poverty threshold of $\$ 13,020$ for a one-parent, one-child family. Further, most workers employed at or near the minimum wage are not offered (or cannot afford) health insurance from their employer, leaving them with a high probability of being uninsured. 
Moving into a job that pays more than the minimum wage is critical for families who want to achieve an above-poverty lifestyle. Recent work has examined the extent to which workers remain in minimum-wage jobs, including whether young workers move up and out. Carrington and Fallick (2001) use the National Longitudinal Study of Youth, which provides data on workers who were between the ages of 14 and 22 in 1979, to follow workers over their first 10 years of postschool labor-market participation. They find that very few workers are still in minimum-wage jobs years into their careers and only 12.2 percent of workers are in minimum-wage jobs plus $\$ 1.00$ a full 10 years into their careers. Using data from the mid-1980s panels of the Survey of Income and Program Participation (SIPP), Smith and Vavrichek (1991) found that 63.0 percent of all minimum-wage workers-young workers included-were employed at higher-than minimum-wage jobs a year later.

However, the issue for working families stuck in low-paying work may be very different than for young workers just getting their start in the labor market. This article evaluates whether prime-age workers get stuck in minimum-wage jobs and finds that over a third are still in minimum-wage jobs three years later. The probability of moving out of a minimum-wage job is higher for men, native-born citizens, those with union jobs, and those that change industry and/or occupation. The probability of staying in a minimum-wage job was greater in the early and mid-1990s, as compared to the late 1990s and early 2000s. The low unemployment and strong wage growth of the late 1990s meant that many more minimum-wage workers were able to move up the job ladder, compared to periods of higher unemployment.

The analysis examines the probability of staying in a minimum-wage job over four different 3-year periods, from 1992 to 1994, 1993 to 1995,1996 to 1999, and 2001 to 2003. This analysis differs from previous research because it purposefully excludes young and older workers, focusing on workers in their prime work years, aged 25 to 54 . For the purposes of this article, a minimumwage worker is defined as someone earning less than or equal to $\$ 1.00$ above the 1997 minimum wage of $\$ 5.15$, in inflation-adjusted terms.

\section{Background}

The share of workers currently earning the minimum wage is relatively small because the value of the minimum wage has been eroded since 1997 by inflation (Table 1). In 2003, only 8.9 percent of women and 5.6 percent of men earned the minimum wage. Still, in 1998, just after the last minimum-wage increase, only 14.4 percent of women and 8.3 percent of men were earning the minimum wage.

In order to examine changes in the probability of moving out of minimumwage jobs over time, this article uses the 1997 value of the minimum wage, in inflation-adjusted dollars, which provides a consistent threshold over time. Using the actual minimum wage would bias the analysis because in the years when Congress increased the minimum wage, it would be harder to move above 
Table 1. Minimum-wage and Low-wage Prime-age Workers

\begin{tabular}{|c|c|c|c|c|}
\hline & \multicolumn{2}{|c|}{$\begin{array}{l}\text { Share earning less than } \\
\text { or equal to } \$ 1 \text { above } \\
\text { the minimum wage (\%) }\end{array}$} & \multicolumn{2}{|c|}{$\begin{array}{l}\text { Share earning at least } \\
\$ 2 \text { above the } \\
\text { minimum wage (\%) }\end{array}$} \\
\hline & Men & Women & Men & Women \\
\hline 1992 & 8.6 & 16.4 & 86.2 & 75.3 \\
\hline 1998 & 8.3 & 14.4 & 87.0 & 77.1 \\
\hline \multirow[t]{3}{*}{2003} & 5.6 & 8.9 & 92.1 & 87.5 \\
\hline & \multicolumn{2}{|c|}{ Low-wage (\%) } & \multicolumn{2}{|c|}{ Above low-wage (\%) } \\
\hline & Men & Women & Men & Women \\
\hline 1992 & 9.0 & 16.9 & 85.5 & 74.2 \\
\hline 1998 & 8.4 & 14.5 & 86.5 & 76.2 \\
\hline \multirow[t]{3}{*}{2003} & 7.7 & 12.3 & 87.3 & 79.8 \\
\hline & \multicolumn{2}{|c|}{ Mean wage (\$) } & \multicolumn{2}{|c|}{ Median wage (\%) } \\
\hline & Men & Women & Men & Women \\
\hline 1992 & 15.41 & 11.83 & 12.99 & 10.11 \\
\hline 1998 & 16.50 & 12.78 & 13.21 & 10.30 \\
\hline 2003 & 17.21 & 13.66 & 13.45 & 11.04 \\
\hline
\end{tabular}

Source: Center for Economic and Policy Research (CEPR) analysis of the 1992, 1993, 1996, and 2001 Survey of Income and Program Participation (SIPP) panels.

Note: Sample is composed of workers ages 25 to 54 . "Low-wage" and "above low-wage" workers earn less than or equal to $\$ 6.15$ and at least $\$ 8.15$ in constant 1997 dollars, respectively.

the minimum-wage level. However, in years that Congress let inflation erode the inflation-adjusted value of the minimum wage, it would be easier to find jobs paying above the nominal minimum-wage threshold. Using a consistent threshold gets at how hard it is to move above low-wage-near minimum wage-work.

Even this constant low-wage measure, however, shows change in the share earning low wages over time. The middle panel of Table 1 shows that in 1992, 16.9 percent of women and 9.0 percent of men earned below this threshold, but by 2003 , these shares had fallen to 12.3 and 7.7 percent, respectively. During the recession of the early 2000s, there were more low-wage workers out of work. Further, wages grew for the first couple of years of the labor-market downturn, through most of 2003 so that it became easier to move into jobs paying above the minimum wage.

\section{Moving on Up?}

The relatively small share of workers earning low wages belies the reality of how few make the transition out of a low-wage job. Table 2 shows the probability of transitioning in and out of low-wage jobs over the period from 1992 
Table 2. Transitions from Low-wage Jobs for Prime-age Workers

\begin{tabular}{lccc}
\hline Percent & $\begin{array}{c}\text { Stayed in } \\
\text { low-wage job }\end{array}$ & \multicolumn{2}{c}{ Moved to } \\
\cline { 3 - 4 } & & Not employed & Above low-wage job \\
\hline All & 36.6 & 24.2 & 39.2 \\
Male & 33.9 & 18.5 & 47.6 \\
Female & 41.0 & 26.5 & 32.5 \\
Native U.S. citizen & 35.5 & 24.1 & 40.4 \\
Foreign-born & 47.3 & 23.4 & 29.4 \\
Less than high school & 48.8 & 30.9 & 20.3 \\
High-school graduate & 44.9 & 23.7 & 31.3 \\
Some college & 33.9 & 20.5 & 45.6 \\
College graduate & 20.0 & 17.7 & 62.3 \\
\hline
\end{tabular}

Source: CEPR analysis of the 1992, 1993, 1996, and 2001 SIPP panels.

Note: See notes to Table 1.

through 2003. One quarter of workers (24.2 percent) transitioned from lowwage jobs to nonemployment, while over a third (36.6 percent) stayed in lowwage jobs, and 39.2 percent transitioned into an above low-wage job.

Women and foreign-born workers are more likely to stay in low-wage jobs: 41.0 percent of women and 47.3 percent of foreign-born workers stayed in a low-wage job, compared to 33.9 percent of men and 35.5 percent of native U.S. citizens. Women were most likely to transition from a low-wage job into nonemployment, while foreign-born workers were less likely to transition into nonemployment, compared to native U.S. born workers. Women and foreign-born workers were also more likely than other demographic groups to move from an above-low-wage job to a low-wage job or into nonemployment (not shown).

Educational attainment plays a large role in who moves out of low-wage employment. Nearly half of workers without a high-school degree (48.8 percent) were still in a low-wage job three years later, while only one-in-five (20.3 percent) had moved to a job paying above low wages. By contrast, among college graduates, only one-in-five (20.0 percent) were still in a low-wage job three years later and two thirds (62.3 percent) had moved to a job paying above low wages.

All else equal, among workers ages 25 to 54 employed three years later, the regression-adjusted probability of remaining in a low-wage job is 36.6 percent. Thus, nearly four out of every ten low-wage workers will still be earning low wages three years later, if they are employed. ${ }^{2}$

The probability of staying in a low-wage job varies by the characteristics of the worker and the job he or she holds. Table 3 summarizes the relative probabilities of remaining in a low-wage job over three years. The rows in this table indicate the effect of having that characteristic. The probability shown in each row is calculated for that row only, with all other variables remaining at their mean. Thus, reading across the first row, women's probability of staying in a minimum-wage job is 9.6 percentage points greater than for men.

Other findings stand out: 
Table 3. Probability of Staying in Low-wage Work: Demographic Effects

\begin{tabular}{lc}
\hline $\begin{array}{l}\text { Discrete predicted probabilities } \\
\text { (percentage point) }\end{array}$ & $\begin{array}{c}\text { Difference in probability of being a low-wage } \\
\text { worker in year 3, if low-wage worker in year 1 }\end{array}$ \\
\hline Women, relative to men & $9.6^{* * *}$ \\
Relative to white workers & $6.0^{* * *}$ \\
$\quad$ African American & 3.3 \\
Hispanic (any race) & 0.4 \\
Other & $9.4^{* * *}$ \\
Foreign-born, relative to U.S. natives & $29.5^{* * *}$ \\
Relative to college-educated workers & $20.6^{* * *}$ \\
$\quad$ Less than high school & $10.9^{* * *}$ \\
High school & $0.2^{*}$ \\
Some college & \\
One year change in age & \\
\hline
\end{tabular}

Source: CEPR analysis of 1992, 1992, 1996, and 2001 SIPP panels.

Notes: Sample is composed of workers ages 24 to 54 . In order to isolate the effects of specific variables, the probability is estimated for the variable in each row with values for all other variables set at their mean. Probabilities are estimated from the first model, as described in Appendix B.

${ }^{* * *}$ significant at the 1.0 percent level; * significant at the 10.0 percent level.

- Foreign-born workers are 9.4 percentage points more likely to stay in a lowwage job, compared to native-born workers;

- Workers without a high-school degree are 29.5 percentage points more likely to stay in a low-wage job and those with a high-school degree are 20.6 percentage points more likely, compared to workers with a college degree;

- The race effects are smaller than for other characteristics, indicating that once we control for other factors, race does not play as large a role in keeping workers in low-wage jobs.

Demographics clearly play a large role in determining who will move up and out of low-wage work. Some of these factors are within worker's controlsuch as improving educational attainment—however, some-such as gender and nativity-are not.

Job-related characteristics also play a strong role in determining who stays in low-wage jobs. Table 4 shows that the effect of moving in or out of an industry with a high concentration of low-wage jobs or a union job has a significant effect on the probability of staying in a low-wage job.

Changing jobs help low-wage workers move up the ladder. Workers who did not change jobs at all during the 3-year period had a higher probability of staying in a low-wage job. The findings suggest that the number of job changes does not affect the probability of moving out of a low-wage job. Workers who changed either their industry or occupation had a lower probability of remaining in a low-wage job. Thus, those who changed not only their job, but the kind of job they held had a greater chance of moving out of low-wage work.

Staying in an industry with a high concentration of low-wage workers (agriculture, retail trade, private household services, personal services, entertainment 
Table 4. Probability of Staying in Low-wage Work: Job-related Effects

\begin{tabular}{lc}
\hline $\begin{array}{l}\text { Discrete predicted probabilities (percentage } \\
\text { point) }\end{array}$ & $\begin{array}{c}\text { Difference in probability of being a low-wage worker } \\
\text { in year 3, if a low-wage worker wage in year } 1\end{array}$ \\
\hline $\begin{array}{l}\text { Relative to changing jobs once or twice } \\
\text { Did not change jobs }\end{array}$ & $5.0^{* * *}$ \\
Changed jobs three or more times & 0.4 \\
Changed industry & $-4.6^{* * *}$ \\
Changed occupation & $-11.6^{* * *}$ \\
Relative to never being in a low-wage industry & 0.4 \\
Moved out of low-wage industry & $20.6^{* * *}$ \\
Stayed in low-wage industry & $20.1^{* * *}$ \\
Moved into low-wage industry & $-16.1^{* * *}$ \\
Relative to never having union job & $-15.2^{* * *}$ \\
Moved into union job & $-15.1^{* * *}$ \\
Stayed in union job & $-5.3^{* * *}$ \\
Moved out of union job & \\
State has a minimum wage higher than federal & Thim
\end{tabular}

Source: CEPR analysis of 1992, 1992, 1996, and 2001 SIPP panels.

Note: See notes to Table 3.

*** significant at the 1.0 percent level.

and recreation services, social services, or forestry), compared to leaving such an industry, significantly increases the probability of remaining in low-wage work. Those workers who moved into these industries also had a significantly higher probability of remaining in low-wage work. Moving out of or never working in an industry with a high concentration of low-wage workers does not, however, reduce the probability of staying in low-wage work.

Being in a union matters. Workers who either started out or ended the three-year period in a union job have a significantly lower probability of staying in a low-wage job, compared to those who were never in a union job. Even if a worker moves from a union to a nonunion job, the union premium follows them.

Finally, policy also plays a role. Workers who live in states that have enacted a state minimum wage higher than the federal minimum wage have a lower probability of staying in a low-wage job. States that have set a higher minimum wage may also have other kinds of policies that help workers move up the job ladder, so this may be representing overall state conditions.

Table 5 highlights what these findings mean for particular groups. Women without a high-school degree and born in the United States have a 69.1 percent chance of still being in a low-wage job three years later. However, a similar woman who is foreign-born has a higher probability-76.5 percent. Both foreign- and native-born men have a lower probability of staying in a low-wage job within educational groups, compared to women.

Women who have a high-school degree have a lower probability of still being in a low-wage job three years later. However, nonnative women with a high-school degree have a probability of remaining in low-wage work that is more comparable to women without a high-school degree, as their probability is 67.3 percent. 
Table 5. Probability of Being in Low-wage Work in Year 3, if Low-wage in Year 1

\begin{tabular}{lccccc}
\hline Individual predicted probabilities (percent) & \multicolumn{2}{c}{ Less than high-school } & & \multicolumn{2}{c}{ High-school } \\
\cline { 2 - 3 } \cline { 5 - 6 } & Male & Female & & Male & Female \\
\hline Native U.S. citizen & 60.2 & 69.1 & & 48.9 & 58.6 \\
Foreign-born & 68.8 & 76.5 & & 58.2 & 67.3 \\
Moved out of high minimum-wage industry & 61.9 & 70.7 & & 50.7 & 60.4 \\
Stayed in high minimum-wage industry & 73.0 & 80.0 & 63.1 & 71.7 \\
Moved into union job & 45.0 & 54.8 & & 34.1 & 43.4 \\
Had union job both times & 45.8 & 55.6 & & 34.8 & 44.2 \\
\hline
\end{tabular}

Source: CEPR analysis of 1992, 1992, 1996, and 2001 SIPP panels.

Note: See notes to Table 3.

Table 6. Probability had been Low-wage Worker in Year 1, if Low-wage in Year 3

\begin{tabular}{lccccc}
\hline Individual predicted probabilities (percent) & \multicolumn{2}{c}{ Less than high-school } & & \multicolumn{2}{c}{ High-school } \\
\cline { 2 - 3 } \cline { 6 - 7 } & Male & Female & & Male & Female \\
\hline Native U.S. citizen & 73.5 & 82.3 & & 62.7 & 73.7 \\
Foreign-born & 81.5 & 88.0 & & 72.6 & 81.6 \\
Moved out of high minimum-wage industry & 88.6 & 92.8 & & 82.4 & 88.7 \\
Stayed in high minimum-wage industry & 84.8 & 90.3 & & 77.1 & 84.9 \\
Moved into union job & 67.8 & 77.9 & & 56.0 & 68.0 \\
Had union job both times & 57.2 & 69.1 & & 44.7 & 57.4 \\
\hline
\end{tabular}

Source: CEPR analysis of 1992, 1992, 1996, and 2001 SIPP panels.

Note: See notes to Table 3.

The middle rows show how moving out of high minimum-wage industries helps workers move beyond low-wage work, compared to those who stayed in minimum-wage industries. Women without a high-school degree have an 80.0 percent chance of still being in low-wage work if they stayed in an industry with a high concentration of minimum-wage workers. If they moved out of one of these industries, their probability drops to 70.7 percent, which is still high.

If, however, a woman without a high-school degree gets into a union job, her probability of staying in low-wage work drops to 54.8 percent. Men with a high-school degree who make the transition into a union job have a relatively low probability—34.1 percent—of still being in a low-wage job three years later.

\section{Or Falling Down?}

Another way to look at movement out of low-wage jobs is to examine the characteristics of workers who end up in them at Year 3. Table 6 shows the probability that a worker had been in a low-wage job, if they ended up in one in Year 3 . This table shows a high degree of stasis-most workers in low-wage work in Year 3 had been there in Year 1.

For women without a high-school degree who ended up in a low-wage job in Year 3, the probability that they had been in a low-wage job in Year 1 is relatively high, regardless of their nativity status, or whether they moved out of a 
Table 7. Probability of Low-wage Work in Year 3, if Low-wage in Year 1

\begin{tabular}{lccccc}
\hline Individual predicted probabilities (percent) & \multicolumn{2}{c}{ Less than high-school } & & \multicolumn{2}{c}{ High-school } \\
\cline { 2 - 3 } \cline { 5 - 6 } & Male & Female & & Male & Female \\
\hline Native U.S. citizen & 4.6 & 6.6 & 2.9 & 4.1 \\
Foreign-born & 5.6 & 8.0 & 3.5 & 5.0 \\
Moved out of high minimum wage industry & 6.6 & 9.3 & 4.2 & 5.9 \\
Stayed in high minimum-wage industry & 10.5 & 14.6 & 6.7 & 9.5 \\
Moved into union job & 2.9 & 4.2 & 1.8 & 2.6 \\
Had union job both times & 2.3 & 3.3 & 1.4 & 2.1 \\
\hline
\end{tabular}

Source: CEPR analysis of 1992, 1992, 1996, and 2001 SIPP panels.

Note: See notes to Table 3.

high minimum-wage industry. If, however, they made it into a union job, their probability of having had a low-wage job three years ago is somewhat smaller.

Men with a high-school degree who had been in a union job in both years have a relatively low probability, 44.7 percent, of having been in low-wage work in Year 1.

Another way to look at the movement out of minimum-wage jobs is to see who "falls down into" a low-wage job. Table 7 shows that the greatest probability of falling into low-wage employment is for women without a high-school degree who stayed in an industry with a high concentration of minimum-wage jobs. Their probability is 14.6 percent, still quite low relative to the probability of a low-wage worker staying in low-wage work.

Men and women in union jobs, regardless of educational attainment, who begin in above low-wage work are very unlikely to end up in low-wage work, with probabilities around 2.0 to 3.0 percent.

\section{Employment and the Macroeconomy}

The overall macroeconomy and the level of labor demand also play a role in the probability that workers will earn above low wages (Table 8). The probability of still being in a low-wage job three years later was great in the early 1990s, compared to the late 1990s and early 2000s. Between 1992 and 1994, the probability of remaining in a low-wage job was 53.7 percent, compared to 44.6 percent in the early 2000s. The difference between the early and late 1990s is statistically significant, which makes sense given how rapidly wages grew in the labor market—especially the low-wage labor market—over the late 1990s and into the early 2000s.

The effects of the macroeconomy on the probability of being in a low-wage job must also take into account the probability of staying employed. Table 9 shows the probability of being employed three years later for those in low-wage and above low-wage jobs in Year 1, as well as the probability that the worker had been employed in Year 1, if they are a low-wage worker in Year 3. 
Table 8. Probability of Staying at the Minimum Wage: Macroeconomy Effects

\begin{tabular}{lc}
\hline $\begin{array}{l}\text { Discrete predicted probabilities } \\
\text { (percentage point) }\end{array}$ & $\begin{array}{c}\text { Difference in probability of earning minimum wage } \\
\text { in year 3, if earned minimum wage in year 1 }\end{array}$ \\
\hline $\begin{array}{l}\text { Relative to the late 1990s (1996 to 1998) } \\
1992 \text { to } 1994\end{array}$ \\
1993 to 1995 & $11.9^{* * *}$ \\
2001 to 2003 & $8.4^{* * *}$ \\
\hline
\end{tabular}

Source: CEPR analysis of 1992, 1992, 1996, and 2001 SIPP panels.

Note: See notes to Table 3.

*** significant at the 1.0 percent level.

Table 9. Probability of being Employed

\begin{tabular}{lcc}
\hline $\begin{array}{l}\text { Discrete predicted probabilities } \\
\text { (percentage point) }\end{array}$ & \multicolumn{2}{c}{ Probability employed in year 3} \\
\cline { 2 - 3 } & If low-wage in year 1 & If above low-wage in year 1 \\
\hline Women, relative to men & $-5.8^{* * *}$ & $-2.8^{* * *}$ \\
Relative to white workers & & $-1.6^{* * *}$ \\
African American & $-6.6^{* * *}$ & $-2.8^{* * *}$ \\
Hispanic (any race) & $-6.0^{* * *}$ & -0.8 \\
Other & -1.0 & $-2.5^{* * *}$ \\
Foreign-born, relative to U.S. natives & 2.1 & $-3.7^{* * *}$ \\
Relative to college-educated workers & & -0.6 \\
Less than high school & $-9.0^{* * *}$ & 0.0 \\
High school & -2.9 & 0.4 \\
Some college & $-3.5^{* *}$ & \\
Has children, relative to no children & $-2.5^{* *}$ & 0.2 \\
Relative to the late 1990s (1996 to 1998) & & 0.3 \\
1992 to 1994 & -1.4 & $-9.4^{* * *}$ \\
1993 to 1995 & 0.6 & $-10.3^{* * *}$ \\
2001 to 2003 &
\end{tabular}

Source: CEPR analysis of 1992, 1992, 1996, and 2001 SIPP panels.

Note: See notes to Table 3.

*** significant at the 1.0 percent level.

During the recession of the early 2000s, low-wage workers had a 10.3 percentage point lower probability of still being employed three years later, compared to similar workers during the late 1990s economic boom. The lower probability of employment is not statistically different from that of the early 1990s, also a period of recession, but one in which job growth resumed sooner than during the early 2000s.

There are differences in the probability of employment across specific groups of workers. Women who begin as low-wage workers have a 5.8 percentage point lower probability of being employed three years later, compared to men; however, women who began at an above low-wage job have only a 2.8 percentage point lower probability of still being employed.

African American workers who begin in low-wage jobs are 6.6 percentage points less likely to still be employed three years later, compared to white workers. However, African Americans who found above low-wage jobs have 
only a 1.6 percentage point difference in the likelihood of remaining employed, compared to whites.

Having children only has a negative effect on staying employed for those who begin in low-wage jobs; for those who begin in an above low-wage job, a parent's probability of still being employed three years later is equivalent to nonparent's. This is a critical finding because so few low-wage workers have access to work/family policies and paid leave.

\section{Conclusions}

Prime-age workers get trapped in minimum-wage jobs, especially during periods of relatively high unemployment and limited wage growth. Prior research has focused on whether all workers are likely to move out of minimumwage jobs; this analysis focuses in on prime-age workers and finds that if they are in a minimum-wage job, many are not likely to move into a job paying above that wage level. Over one third of all low-wage workers were still in low-wage jobs three years later.

Strong labor demand does help. During the late 1990s when unemployment was low, workers were more likely to move out of low-wage jobs. Policy makers who want to focus on eradicating poverty should look to policies that generate high levels of employment and low unemployment, which will both provide more opportunities for low-wage workers to move up the job ladder, but will also put pressure on wages at the low end, as occurred during the late 1990s.

It is unfortunate that a policy designed to ensure an adequate floor for wages has eroded so much that a worker with one child will be nearly $\$ 3,000$ below the poverty line if he or she works at minimum wage full-time, full-year. Now, minimum-wage jobs are something to be escaped. Unfortunately, few adults in minimum-wage jobs are able to "escape" them over a 3-year period, especially if they are female, nonnative, or not lucky enough to have a union job. Changing jobs does help, as those who are able to move into a different industry and/or occupation are more likely to get out of minimum-wage work.

When policy makers talk of the minimum wage, they generally speak to its role as the floor for wages. However, when thinking about helping workers to achieve economic well-being and provide for their families, policy makers should also consider how workers move onto better-paid jobs. Job ladders-or the lack thereof-are critical to ensuring that the minimum wage is a floor for those starting out in the labor market, not a place where prime-age workers are likely to get stuck.

\section{Appendix A: Data}

The data for this analysis came from the 1992, 1993, 1996, and 2001 panels of the Survey of Income and Program Participation (SIPP), which cover the period from 1992 through 2003. The sample includes workers ages 25 to 54 . All data is weighted using the SIPP monthly weights. 
The time frame includes the first six and last six complete months of each SIPP panel, except for the 1996 panel where the time frame includes the first six complete months and the last six complete months in the third year of the panel. For all variables, the individual is coded as having a characteristic if they had it for three or more months in the six-month period (except in the case of low-wage workers, described below). For example, to be recorded as in the retail trade industry in the first time period of the 1996 panel, the individual had to report working in retail trade for at least three of the six months from March to August 1996.

The dependent variable is whether or not the individual was a low-wage worker in their primary job. Since this study is looking at the ability of workers to move out of "minimum wage" jobs over time, a constant definition of the minimum wage is used, to separate out the macroeconomic effects and the effects of changes in the minimum wage that occurred in 1996 and 1997 at the federal level and various years for particular states. The measure is the 1997 minimum wage, $\$ 5.15$, in constant 1997 dollars. A low-wage worker earns below $\$ 1.00$ above $\$ 5.15$ in at least three months in the six-month time period. An above low-wage worker is considered to be when a worker earns more than $\$ 2.00$ above $\$ 5.15$ in at least three months in the six-month time period.

The wage variable used to generate whether an individual is above or below the minimum wage is hourly wages. SIPP respondents can report either hourly wages or monthly earnings; we calculate hourly wages for observations without wage data, but with valid data for both earnings and hours per week. The wage data is adjusted for topcoding. (See Boushey (2004) and Boushey and Schmitt (2004) for a complete analysis of SIPP wage data.) The dependent variable for the employment model is whether the respondent indicated a positive value for wages or earnings that month.

A primary job is the job in that month at which the individual works the most hours. The SIPP provides information on up to two jobs for each respondent each month. Each job is given a unique number so that the analysis can be conducted on tenure within a specific firm. Job tenure is calculated from the reported start date of employment and includes months worked at that job prior to, and during the SIPP panel.

\section{Appendix B: Method}

This paper predicts the probability of moving out of a low-wage job over a three-year period. For any individual low-wage worker in year 1 , in year 3, they could either be out of employment, earning the minimum wage, or earning above the minimum wage. The calculated probabilities presented in the tables are based on the regression results. Full regression results are available from the author upon request.

The first set of models predicts the likelihood of staying in low-wage jobs. These models include controls for age, race/ethnicity, gender, educational attainment, nativity, year, whether the individual's state has a minimum wage 
higher than the federal minimum wage at any time over the entire time period, whether the individual changed industry (23) or occupation (14), whether the individual moved into or out of an industry with a high concentration of minimum wage workers, whether the individual moved into or out of a union job, and the number of job changes the individual made over the three years. The estimates include one observation per person.

The second set of models predicts the likelihood of employment. These models include controls for age, race/ethnicity, gender, educational attainment, nativity, marital status, disability status, presence of children in the family, and year. The estimates include one observation per person.

Heather Boushey is an economist at the Center for Economic and Policy Research in Washington, DC. Her e-mail is hboushey@cepr.net.

\section{Notes}

This project benefited greatly from the research assistance of Joseph Wright and Wei Wei. John Schmitt and Dean Baker provided helpful comments. The Rockefeller Foundation and the Annie E. Casey Foundation have generously supported this research.

1. This calculation includes workers earning the minimum wage (\$5.15) or less in 2001, 2002, or 2003.

2. Regression results available from author.

\section{References}

Boushey, H. 2004. Notes on set D: Labor market and employment outcomes. Washington, DC: Center for Economic and Policy Research.

— and J. Schmitt. 2004. Using wage data from the Survey of Income and Program Participation (SIPP). Washington, DC: Center for Economic and Policy Research.

Carrington, W. J., and B. C. Fallick. 2001. Do some workers have minimum wage careers? Montbly Labor Review 124:17-27.

Chapman, J., and M. Ettlinger. 2004. The who and why of the minimum wage: Raising the wage floor is an essential part of a strategy to support working families. Washington, DC: Economic Policy Institute.

Smith, R. E., and B. Vavrichek. 1991. The wage mobility of minimum wage workers. Industrial and Labor Relations Review 46:82-8. 